\title{
Russian science academy rejects Putin ally
}

Mikhail Kovalchuk's rise to the top position in Russian science seemed a done deal. But the general assembly of the Russian Academy of Sciences has thwarted plans for the head of its newly established division for nanosciences to become the influential academy's new president.

Russia's then president Vladimir Putin last year chose Kovalchuk to head Russia’s US\$7-billion push into nanotechnology. A few weeks later, the academy's leadership appointed Kovalchuk as 'acting' vicepresident for nanotechnology.

Kovalchuk is the director of the Kurchatov Institute in
"It seemed obvious that Osipov would merely keep the position for Kovalchuk." successful banker with close personal ties to Putin - has earned his merits as a skilled science administrator with influential contacts in political and business circles. He has also done research, mostly in crystallography, but his achievements and publication record are not considered outstanding.

Nonetheless, observers expected that the academy's long-time president, mathematician Yuri Osipov, who was on 30 May re-elected for the fourth time, would just be a placeholder for Kovalchuk (see 'Presidential election disappoints reformists'). Osipov's rival candidate, highMoscow, Russia's premier centre for nuclear science. But as he was not a full member of the academy (only a 'corresponding' member), he could not be elected president. In preparation for the election, last week's general assembly was expected to grant him full membership. But on 28 May he failed to win the two-thirds majority vote necessary for membership, by 44 votes.

According to the academy's rules, full membership is restricted to individuals who have contributed in a ground-breaking way to the advancement of science. Kovalchuk - whose older brother, Yuri Kovalchuk, is a

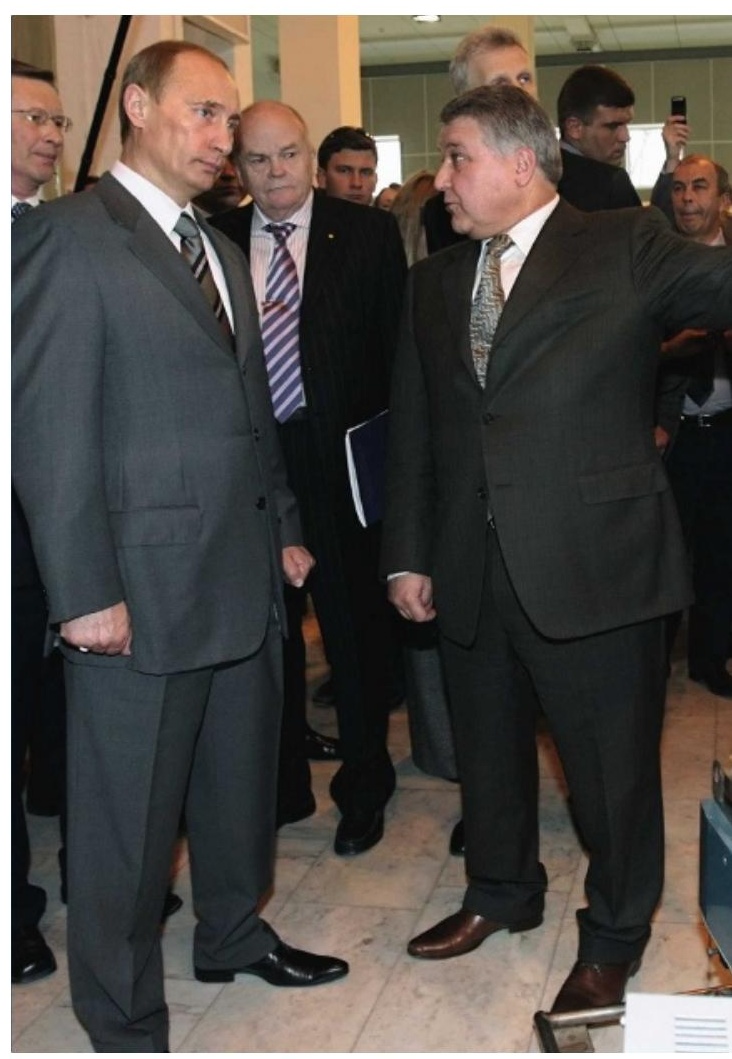

say suffers from prevailing Soviet structures and widespread lack of competition (see Nature 449, 524-527; 2007).

"Nobody really believed that Osipov intended to remain president for very long," says biologist Mikhail Gelfand, a Howard Hughes International Research Scholar and vice-president for science at the academy's

\section{Presidential election disappoints reformists}

The re-election of Yuri Osipov as president of the Russian Academy of Sciences is a bitter disappointment for the many Russian scientists who had hoped for a regime change.

With 651 votes for Osipov in Friday's election, the 71-year-old mathematician succeeded over two younger rivals, physicist Vladimir Fortov and ecologist Valery Chereshnev, who ended up with 486 and 88 votes, respectively.

Osipov has been criticized in the past for standing in the way of reform, which many scientists think is urgently needed to restore the strength and reputation of Russia's best-known scientific brand. In an open letter to the general assembly, Alexander Spirin, one of Russia's most highly recognized biochemists, warned that Osipov's re-election would cement the academy's reputation for being stubbornly opposed to introducing changes such as international peer review and open competition for funding.

Fortov, who served as Russian science minister from 1996 to 1998 and who then became the first president of the Russian Foundation for Basic Research, said he would increase the fraction of research money distributed by open competition. He also planned to create closer ties with the scientific 'diaspora', the large number of scientists who emigrated from the country when they became disillusioned about the state of Russian science. And he intended to promote the recruitment of talented young scientists to Moscow, by helping them buy apartments in Russia's incredibly expensive capital.

Osipov has not yet outlined a detailed work programme for his fourth term in office. He is said to be open to the idea of building houses for young scientists on land that belongs to the academy. Other than that, he received crucial support from Prime Minister Vladimir Putin, who told the assembly on 29 May that the government will sharply increase academy members' salaries. Full members can now expect their monthly bonus payments to rise from around 24,000 rubles (US\$1,000) to 50,000 rubles. Rank-and-file scientists, who often get less than $\$ 300$ per month, may well come away empty handed.

"Few 'ordinary' scientists employed by the academy, me included, would have voted for Osipov," says Konstantin Severinov, a molecular biologist at the academy's Institute of Molecular Genetics in Moscow.

Critics say that the academy is increasingly giving up its scientific ideals for power and moneymaking purposes. "With its many vested interests the current leadership is losing its moral standing," says Gelfand. "Fortov would have meant a real change. Alas, it was not to be." Q.S. 
